\title{
Availability of adequately iodized in Northwest Ethiopia: a cross-sectional study

Zegeye Abebe ${ }^{1 *}$, Amare Tariku and Ejigu Gebeye ${ }^{2}$

\begin{abstract}
Background: Universal salt iodization is the most cost-effective, safe and sustainable strategy to eliminate iodine deficiency disorders. However, little is known about the availability of adequately iodized salt in the northwestern part of Ethiopia. Thus, the aim of this study was to assess the availability of adequately iodized salt at the household level and associated factors in Dabat District, northwest Ethiopia.

Methods: A community-based cross-sectional study was conducted from February 21 to March 31, 2016. We included 705 households in the study. A stratified multistage followed by simple random sampling technique was employed to select households. The level of salt iodine content was determined using the rapid field test kit. Accordingly, the value of $<15$ parts per million (PPM) and $\geq 15$ PPM with the corresponding color chart on the rapid test kit were used to classify the level of iodine content in the sampled salt. A multivariable binary logistic regression model was fitted to identify factors associated with the availability of adequately iodized salt. Adjusted Odds Ratio (AOR) with the corresponding 95\% Confidence Interval (Cl) was calculated to show the strength of association.

Results: This study indicated that about 33.2\% [95\% Cl: 29.6, 36.7\%] of households had adequately iodized salt. Urban residence ( $\mathrm{AOR}=2.15,95 \% \mathrm{Cl}: 1.23,3.76)$, use of packed salt (AOR $=2.23,95 \% \mathrm{Cl}: 1.01,4.89)$, and good respondents' knowledge on iodized salt use ( $\mathrm{AOR}=1.49,95 \% \mathrm{Cl}: 1.08,2.08)$ were positively associated with the availability of adequately iodized salt. However, longer distance to buy salt was inversely related with availability of adequately iodized salt (AOR $=0.68,95 \% \mathrm{Cl}: 0.48,0.99)$.

Conclusions: The availability of iodized salt is well under the WHO recommendation in Dabat District in spite of the fact that Ethiopia has been implementing universal salt iodization since the last five years. Therefore, intensifying strategies targeting to enhance community awareness on the benefit and handling practice of iodized salt is essential to improve availability of iodized salt. In addition, the focus needs to be on improving accessibility of iodized salt.
\end{abstract}

Keywords: lodized salt, Knowledge, Residence, Distance, Ethiopia

\section{Background}

Iodine is important for thyroid hormone production, hence, it has a critical role in supporting brain development, control of metabolic function, and reproduction [1, 2]. According to the World Health Organization (WHO) recommendation, a preschool children needs about $90 \mu \mathrm{g}$ of iodine per day to prevent iodine deficiency (ID) [1].

Iodine deficiency is a major public health problem, especially in children and pregnant women [3]. It is known to cause mental retardation, goiter, miscarriage, still birth,

\footnotetext{
* Correspondence: zegeye24@gmail.com

${ }^{1}$ Department of Human Nutrition, Institute of Public Health, College of Medicine and Health Sciences, University of Gondar, Gondar, Ethiopia

Full list of author information is available at the end of the article
}

premature birth, and increase child mortality, collectively called "iodine deficiency disorders (IDD)" [4-6].

Globally, close to 2 billion population is at risk of ID, while one-third live in areas where natural sources of iodine is low [7]. Universal salt iodization (USI) is recommended as the most cost-effective, safe and sustainable strategy to eliminate IDDs [7]. However, only $75 \%$ of the household's worldwide use iodized salt. This USI coverage is considered as a dramatic increment compared to the 1990 report, $10 \%$ [8].

In terms of the region, an optimal iodized salt utilization (90\%) is reported in East Asia and Pacific countries. In sub-Saharan Africa, $64 \%$ of households are using iodized salt nevertheless the level of utilization 
widely varies from 10 to $90 \%$ in different countries. For instance, utilization of iodized salt is less than 10\% in Sudan, Mauritania, Guinea-Bissau, and Gambia, whereas, in Burundi, Kenya, Nigeria, Tunisia, Uganda, and Zimbabwe, it is more than $90 \%$ [9].

In Ethiopia, utilization of adequately iodized shows a gradual improvement, $4 \%$ in 2000 to $15 \%$ in 2011 and $23 \%$ in 2014 [10, 11]. Disparities in level of utilization are detected with residence and regions. As illustration, iodized salt utilization is high in urban areas and in Amhara, Oromia, and Tigray regions compared to other regions [11].

Furthermore, level of availability of adequately iodized salt depends on other socio-demographic characteristics. Family size [12], economic status [13], mothers educational status [14, 15], knowledge about iodized salt use and prevention of IDDs $[14,16]$, and salt handling practices $[17-20]$ are significantly associated with availability of adequately iodized salt.

Ethiopia is a salt producing state, endorsed mandatory salt iodization program and is working with partners, United Nations Children's Fund (UNICEF) and Micronutrient Initiatives, to reach utilization of iodized salt $>90 \%$ thereby to mitigate ID [21]. But, still only $23.2 \%$ of the households use adequately iodized salt [11]. In addition, ID remains the major public health problem $[22,23]$ among school children and pregnant women $[20,24]$. Even there is high prevalence of goiter in Dabat District, the study area [25]. However, there is a limited information on availability of universal iodized salt in Dabat District. Therefore, this study aimed to investigate the household availability of adequately iodized salt and associated factors in Dabat District, northwest Ethiopia.

\section{Methods}

\section{Study design and setting}

A community-based cross-sectional study was conducted from February 21 to March 31, 2016, in Dabat District, northwest Ethiopia. The district is found $821 \mathrm{~km}$ from Addis Ababa, the capital city of Ethiopia. It lies at an altitude of 1000-2500 meters and has a total population of 175,737 in 26 rural and 4 urban Kebeles (the smallest administration unit in Ethiopia). Cereals, such as maize, sorghum, wheat, and barley are the main staple crops cultivated in the district. The Health and Demographic Surveillance System (HDSS) site was also located in Dabat District. The HDSS site has been running since 1996 and hosted by the University of Gondar. The surveillance site covers 13 randomly selected kebeles (4 urban and 9 rural kebeles) in different ecological zones (high land, middle land, and lowland).

\section{Sample size and sampling procedure}

The sample size of the study was calculated using Open Epi version 2.3 software with the following assumptions; $33 \%$ as the prevalence of availability of iodized salt at the household level [14], 95\% Confidence level, and a 5\% margin of error. Finally, the sample size of 714 households was obtained by considering $5 \%$ non-response rate and a design effect of 2 . A multistage stratified sampling followed by simple random sampling technique was employed to reach the households. Initially, households were stratified into urban and rural kebeles. Of the total13 kebles in the HDSS site, 4(1 urban and 3 rural kebeles) were selected by lottery method. A total number of households in the selected kebeles were obtained from HDSS site, and then the total number of households included in the study was proportionate-to-the household size. Finally, a simple random sampling technique was employed to select the households. Women who were majorly involved in food preparation of the household were interviewed.

\section{Data collection instrument and procedure}

We used a structured interviewer-administered questionnaire to collect data. The questionnaire was first prepared in English and was translated into the local language (Amharic) and finally, back translated to English to maintain consistency.

The pretest was done on five percent of the sample out of the study area. Two days training was given for data collectors and supervisors. A total of seven data collectors (an environmental health professional, and six permanent data collectors of the HDSS site) and two supervisors (two public health experts) were recruited for the study. The rapid test of salt iodine content was done by an environmental health professional who had adequate training (certificate of Training of Trainers) in the determination of salt iodine content. Daily supervision and feedback were carried out by the investigators and supervisors during the entire data collection period to maintain the quality of the data.

\section{Salt iodine content determination}

A tablespoon of salt was collected from each household, and the MBI international Rapid Test Kit (RTK) was used to determine the level of salt iodine content. The small cup in the kit was filled with salt, and made the cup surface flat. Two drops of test solution from white ampoule were added to the surface of the salt by piercing the white ampoule with a pin and gently squeezing the ampoule. The iodine content in the salt was determined within one minute by comparing the color change on the salt with the color chart. The value 0 parts per million (PPM), <15 PPM and $\geq 15$ PPM with the corresponding color chart on the rapid test kit were 
used to classify the level of iodine in the sampled salt. If no color appears (after $1 \mathrm{~min}$ ), 5 drops of the recheck solution from red ampoule was added to a fresh salt sample and followed by 2 drops of test solution on the same salt sample $[1,11]$. Then, a comparison was done with the color chart indicators for salt iodine content. Finally, Availability of adequately iodized salt was considered when the household sampled salt had $\geq 15 \mathrm{ppm}$ iodized salt [1], otherwise, it was classified to inadequately iodized salt.

\section{Assessment of wealth status and maternal knowledge}

The household's wealth index was determined using Principal Component Analysis (PCA) by considering the household assets, quantity of cereal products, type of house, livestock and agricultural land ownership. First, variables were coded between 0 and 1 . Secondly, variables entered and analyzed using PCA, and those variables having a communality value of greater than 0.5 were used to produce factor scores. Finally, the factor scores were summed and ranked into tertiles as poor, medium and rich.

Similarly, the knowledge of the respondents towards iodized salt use were computed by using nine knowledge item questions, including the importance of iodized salt, disorders resulted from ID, food sources of iodine, appropriate place of salt storage, time to add salt during food preparation, salt storage material, and existence of law prohibiting selling non-iodized salt in Ethiopia. Accordingly, the PCA was also used rank respondents' knowledge into not knowledgeable and knowledgeable.

\section{Data processing and analysis}

Data were checked and entered into EPI-Info version 7 and analyzed using SPSS version 20 statistical software. The availability of adequately iodized salt, the outcome variable, was dichotomized into inadequately iodized (0-14PPM) and adequately ( $\geq 15 \mathrm{PPM})$ iodized salt based on the result of rapid test. Descriptive statistics were used to summarize variables. A binary logistic regression was fitted to identify factors associated with the availability of adequately iodized salt. Variables with a p-value less than $<0.2$ in the bivariable analysis and those variables which frequently showed significant association with the availability of adequately iodized salt in the previous studies, regardless of the p-value in the current study, were also fitted into the multivariable binary logistic regression analysis. A backward likelihood ratio method was employed. Both Crude Odds Ratio (COR) and Adjusted Odds Ratio (AOR) with the corresponding 95\% Confidence Interval were estimated to show the strength of association. In multivariable analysis, variables with a $p$-value of $<0.05$ were considered as statistically significant.

\section{Results}

Socio-demographic and economic characteristics

A total of 705 households were included in the study, which makes a response rate of $98.7 \%$. The median age of the respondents was 35 years with Interquartile Range (IQR) of \pm 10 years. About 434 (61.6\%) of the households had a family size of greater than five. Three-quarters of the respondents, 539 (76.5\%), were illiterate (Table 1).

\section{Availability of adequately iodized salt}

In Dabat District availability of iodized salt was 33.2\% (95\% CI: 0.296, 0.367). About 675 (95.7\%) of households used the unpacked type of salt for food preparation out of which 457 (67.7\%) were inadequately iodized. A substantial proportion (95 and 91\%, respectively) of salt was covered and stored away from a fire. However, 355 (50.4\%) of the salt was added at the beginning and middle of food preparation (Table 2).

\section{Respondent's knowledge and attitude towards iodized salt use}

Nearly half, 320 (45.4\%), of the respondents had good knowledge while two-third, 441 (62.6\%), of the respondents had favorable attitude towards iodized salt use. Nevertheless, nearly half, 314 (44.5\%), of them didn't know the importance of using iodized salt (Table 3).

\section{Factors associated with the availability of adequately iodized salt}

To assess the effect of selected variables on the availability of iodized salt in the household, both bivariable and multivariable binary logistic regression analyses were fitted. Accordingly, residence, type of salt used, maternal knowledge and distance traveled to buy salt were associated with the availability of iodized salt in the final model. The higher odds of availability of adequately iodized salt were observed among households located in urban kebeles $(\mathrm{AOR}=2.15 ; 1.23,3.76))$ and used packed type of salt $(\mathrm{AOR}=2.23 ; 1.01,4.89)$. Similarly, the odds of having adequately iodized salt were 1.49 times $(\mathrm{AOR}=1.49 ; 1.08,2.08)$ higher among respondents who had good knowledge towards iodized salt use as compared to their counterparts. Whereas lower odds of availability of adequately iodized salt were found among respondents who traveled a longer distance to buy salt $(\mathrm{AOR}=0.68,95 \% \mathrm{CI}: 0.48,0.99)$ (Table 4$)$.

\section{Discussion}

It is clear that the use of non-iodized salt by households is the major obstacle in the control of IDDs in a given community $[26,27]$. Therefore, regular monitoring of availability of adequately iodized salt is an essential step to eliminate the problem $[28,29]$. Cognizant of the fact, 
Table 1 Socio-demographic and economic characteristics of respondents, Dabat District, northwest Ethiopia, March 2016 $(n=705)$

\begin{tabular}{|c|c|c|}
\hline Variables & Frequency & Percentage \\
\hline \multicolumn{3}{|l|}{ Age of respondents } \\
\hline $16-24$ & 36 & 5.1 \\
\hline $25-34$ & 268 & 38.0 \\
\hline $35-49$ & 330 & 46.8 \\
\hline $50-79$ & 71 & 10.1 \\
\hline \multicolumn{3}{|l|}{ Residence } \\
\hline Urban & 151 & 21.4 \\
\hline Rural & 554 & 78.6 \\
\hline \multicolumn{3}{|l|}{ Mother's marital status } \\
\hline Currently married & 616 & 87.4 \\
\hline Currently unmarried $^{c}$ & 99 & 12.6 \\
\hline \multicolumn{3}{|l|}{ Religion } \\
\hline Orthodox & 689 & 97.7 \\
\hline Muslim & 16 & 2.3 \\
\hline \multicolumn{3}{|l|}{ Mother's education } \\
\hline Illiterate & 539 & 76.5 \\
\hline Primary & 97 & 13.8 \\
\hline Secondary and above & 69 & 9.8 \\
\hline \multicolumn{3}{|l|}{ Husband's education } \\
\hline Illiterate & 390 & 55.3 \\
\hline Primary & 225 & 31.9 \\
\hline Secondary and above & 90 & 12.8 \\
\hline \multicolumn{3}{|l|}{ Mother's occupation } \\
\hline Housewife & 309 & 43.8 \\
\hline Farmer & 319 & 45.2 \\
\hline Merchant & 32 & 4.5 \\
\hline Government employee & 25 & 3.5 \\
\hline Others $^{\mathrm{b}}$ & 20 & 2.8 \\
\hline \multicolumn{3}{|l|}{ Husband's Occupation } \\
\hline Farmer & 571 & 81.0 \\
\hline Merchant & 36 & 5.1 \\
\hline Government employee & 72 & 10.2 \\
\hline Others $^{a}$ & 26 & 3.7 \\
\hline \multicolumn{3}{|l|}{ Family size } \\
\hline$<6$ & 271 & 38.4 \\
\hline$\geq 6$ & 434 & 61.6 \\
\hline \multicolumn{3}{|l|}{ Wealth status } \\
\hline Poor & 237 & 33.6 \\
\hline Medium & 233 & 33.0 \\
\hline Rich & 235 & 33.3 \\
\hline
\end{tabular}

${ }^{a}$ daily laborer, pension; ${ }^{\mathrm{b}}$ students, daily laborer; ${ }^{\mathrm{c}}$ single, divorced, widowed
Table 2 Availability of adequately iodized salt and handling practices, Dabat District, northwest, Ethiopia, March 2016

\begin{tabular}{|c|c|c|}
\hline Variables & Frequency & Percentage \\
\hline \multicolumn{3}{|l|}{ Type of salt } \\
\hline Packed & 30 & 4.3 \\
\hline Unpacked & 675 & 95.7 \\
\hline \multicolumn{3}{|c|}{ Addition of salt during food preparation } \\
\hline At the beginning and the middle & 355 & 50.4 \\
\hline At the end & 350 & 49.6 \\
\hline \multicolumn{3}{|l|}{ Salt exposure to sunlight } \\
\hline Yes & 35 & 5.0 \\
\hline No & 670 & 95.0 \\
\hline \multicolumn{3}{|l|}{ Washing of salt to remove impurities } \\
\hline Yes & 13 & 1.8 \\
\hline No & 692 & 98.2 \\
\hline \multicolumn{3}{|l|}{ Quantity of salt purchased commonly } \\
\hline \multicolumn{3}{|l|}{$<1 \mathrm{~kg}$} \\
\hline $1 \mathrm{~kg}$ & 439 & 62.3 \\
\hline $2-5 \mathrm{~kg}$ & 153 & 21.7 \\
\hline$>5 \mathrm{~kg}$ & 113 & 16.0 \\
\hline \multicolumn{3}{|l|}{ Place of salt storage } \\
\hline Near to the fire & 65 & 9.2 \\
\hline Away from the fire & 640 & 90.8 \\
\hline \multicolumn{3}{|l|}{ Salt storage material } \\
\hline With closed container & 669 & 94.9 \\
\hline Without closed container & 36 & 5.1 \\
\hline \multicolumn{3}{|l|}{ Duration of household salt storage } \\
\hline 1-8 weeks & 642 & 91.1 \\
\hline$\geq 9$ weeks & 63 & 8.9 \\
\hline \multicolumn{3}{|l|}{ Salt iodine content } \\
\hline 0-14PPM & 472 & 66.8 \\
\hline$\geq 15$ PPM & 234 & 33.2 \\
\hline \multicolumn{3}{|l|}{ Distance travel to buy iodized salt } \\
\hline$\leq 60$ min walking & 509 & 72.2 \\
\hline$>60$ min walking & 196 & 27.8 \\
\hline
\end{tabular}

the WHO recommendation recommend utilization of the household iodized salt to be greater than $90 \%$ to eliminate IDDs [1]. Nevertheless, this study found that only $33.2 \%$ (95\% CI: 29.6, 36.7\%), of households had adequately iodized salt. The result is considerably lower than the national goal of reaching $>90 \%$, which alerts the public authorities to consider regular monitoring of the quality of salt at the site of production, wholesale and household level. Strengthening media promotion on efficient utilization of iodized salt, at household level, is very also crucial [30]. 
Table 3 Respondent's knowledge and attitude towards iodized salt use, Dabat District northwest Ethiopia, 2016 ( $n=735)$

\begin{tabular}{|c|c|c|}
\hline Variables & Frequency & Percentage \\
\hline \multicolumn{3}{|l|}{ Respondent's knowledge } \\
\hline Poor & 385 & 54.6 \\
\hline Good & 320 & 45.4 \\
\hline \multicolumn{3}{|l|}{ Respondent's attitude } \\
\hline Unfavorable & 264 & 37.4 \\
\hline Favorable & 441 & 62.6 \\
\hline \multicolumn{3}{|l|}{ Importance of iodized salt ${ }^{\mathrm{a}}$} \\
\hline Prevention of goiter & 110 & 15.6 \\
\hline Growth and development & 16 & 2.3 \\
\hline For health & 364 & 51.6 \\
\hline I don't know & 314 & 44.5 \\
\hline \multicolumn{3}{|l|}{ The richest source of iodine $e^{a}$} \\
\hline Egg & 25 & 3.5 \\
\hline Meat & 37 & 5.2 \\
\hline Milk and milk products & 37 & 5.2 \\
\hline lodized salt & 61 & 8.7 \\
\hline Fish & 8 & 1.1 \\
\hline Fruit and vegetables & 7 & 1 \\
\hline I don't know & 591 & 83.8 \\
\hline \multicolumn{3}{|l|}{ Disorders of lack of iodine $e^{a}$} \\
\hline Mental retardation & 25 & 3.5 \\
\hline Goiter & 174 & 24.7 \\
\hline Retarded growth & 7 & 1 \\
\hline Abortion & 9 & 1.3 \\
\hline Child mortality & 1 & 0.1 \\
\hline I don't know & 501 & 71.1 \\
\hline \multicolumn{3}{|l|}{ All salts contain iodine } \\
\hline Yes & 73 & 10.4 \\
\hline No & 212 & 30.1 \\
\hline I don't know & 420 & 59.6 \\
\hline
\end{tabular}

Existence of law that prevents selling none iodized salt for human/animal consumption

$\begin{array}{lcl}\text { Yes } & 44 & 6.2 \\ \text { No } & 181 & 25.7 \\ \text { I don't know } & 480 & 68.1\end{array}$

Test of iodized salt is different from unionized one

$\begin{array}{lll}\text { Yes } & 175 & 24.8 \\ \text { No } & 267 & 37.9 \\ \text { I don't know } & 263 & 37.3\end{array}$

lodized salt has a harmful effect on health

$\begin{array}{lll}\text { Yes } & 33 & 4.7 \\ \text { No } & 590 & 83.7 \\ \text { I don't know } & 82 & 11.6\end{array}$

Table 3 Respondent's knowledge and attitude towards iodized salt use, Dabat District northwest Ethiopia, $2016(n=735)$ (Continued)

\begin{tabular}{lcc}
\hline Salt obtained from the sea already contain iodine in the right quantities \\
Yes & 97 & 13.8 \\
No & 386 & 54.8 \\
I don't know & 222 & 31.5 \\
\hline
\end{tabular}

${ }^{\text {amultiple responses }}$

On the other hand, the availability of adequately iodized salt in Dabat District (33.2\%) is higher than other urban district of Ethiopia: Assosa (26.1\%) and Gondar (28.9\%) [31, 32]. Likewise, the finding is higher compared to a study in Kenya (26.2\%) [33]. This is probably due to improved effort of local government to ensure market availability of iodized salt, the best strategies to address ID in areas where the natural source of iodine is low. The officials are also giving special emphasis in promoting the health benefit of iodized salt through the local medias to bring the desired public awareness [34].

However, availability of adequately iodized salt is significantly lower than the one observed in India (81.9\%) [35], and Ethiopia (62.9\% [36]. Mother's poor knowledge towards iodized salt and using unpacked type of salt in $80 \%$ of the households could explain the lower prevalence of availability of adequately iodized salt in this study area compared to latter local report. In addition, shorter duration of time in implementation of universal salt iodization compared to India might explain the observed discrepancy.

In this study, respondents from urban kebeles were more likely to have adequately iodized salt compared to those living in the rural settings. This finding is supported by another study in Ethiopia [37]. This could related to better literacy rate and access to media among urban dwellers which might enhance their level of understanding regarding the importance of iodized salt and information access, respectively. In addition, urban respondents have access to media, and iodized salt everywhere and every time. Furthermore, rural residents may prefer using non-iodized salt because they perceived that its low cost and more potency in test compared to iodized one [38].

The study also detected that the odds of availability of adequately iodized salt were higher in households using a packed type of salt than their counterparts using unpacked type of salt. This report is in agreement with another former study from West Ethiopia [37]. It is documented that loss of iodine in salt from a good quality polyethylene packing material is less than $10 \%$ over 18 months period, regardless of the climatic conditions or fine and 
Table 4 Factors associated with the availability of adequately iodized salt in the household, Dabat District, northwest, Ethiopia, March $2016(n=705)$

\begin{tabular}{|c|c|c|c|c|}
\hline \multirow[t]{2}{*}{ Variables } & \multicolumn{2}{|c|}{ Availability of iodized salt } & \multirow[t]{2}{*}{ Crude Odds Ratio 95\% C1 } & \multirow[t]{2}{*}{ Adjusted Odds Ratio 95\% Cl } \\
\hline & $\geq 15 P P M$ & $<15 P P M$ & & \\
\hline \multicolumn{5}{|l|}{ Respondents age in years } \\
\hline $16-24$ & 15 & 21 & $1.82(0.79,4.22)$ & * \\
\hline $25-34$ & 84 & 184 & $1.16(0.65,2.07)$ & * \\
\hline $35-49$ & 115 & 215 & $1.36(0.78,2.40)$ & * \\
\hline $50-79$ & 20 & 51 & 1.00 & * \\
\hline \multicolumn{5}{|l|}{ Residence } \\
\hline Urban & 63 & 88 & $1.60(1.11,2.32)$ & $2.15(1.23,3.76)$ \\
\hline Rural & 171 & 383 & 1.00 & 1.00 \\
\hline \multicolumn{5}{|l|}{ Mother's education } \\
\hline Illiterate & 171 & 368 & 1.00 & * \\
\hline Primary education & 38 & 59 & $1.39(0.89,2.17)$ & * \\
\hline Secondary and above & 25 & 44 & $1.22(0.73,2.06)$ & * \\
\hline \multicolumn{5}{|l|}{ Husband's education } \\
\hline Illiterate & 126 & 264 & 1.00 & * \\
\hline Primary education & 73 & 152 & $1.01(0.71,1.43)$ & * \\
\hline Secondary and above & 35 & 55 & $1.33(0.83,2.14)$ & * \\
\hline \multicolumn{5}{|l|}{ Mother's occupation } \\
\hline Housewife & 99 & 210 & 1.00 & * \\
\hline Farmer & 109 & 210 & $1.10(0.80,1.54)$ & * \\
\hline Merchant & 11 & 21 & $1.11(0.52,2.39)$ & * \\
\hline Government employee & 9 & 16 & $1.19(0.51,2.79)$ & * \\
\hline Others & 6 & 14 & $0.91(0.34,2.44)$ & * \\
\hline \multicolumn{5}{|l|}{ Husband's occupation } \\
\hline Farmer & 13 & 23 & 1.00 & * \\
\hline Merchant & 185 & 386 & $0.85(0.42,1.71)$ & * \\
\hline Government employee & 24 & 48 & $0.89(0.38,2.05)$ & * \\
\hline Others & 12 & 14 & $1.52(0.54,4.24)$ & * \\
\hline \multicolumn{5}{|l|}{ Family size } \\
\hline$\leq 5$ & 96 & 175 & $1.18(0.85,1.62)$ & * \\
\hline$\geq 6$ & 138 & 296 & 1.00 & * \\
\hline \multicolumn{5}{|l|}{ Household wealth index } \\
\hline Poor & 81 & 156 & 1.00 & * \\
\hline Medium & 69 & 164 & $0.81(0.55,1.19)$ & * \\
\hline Rich & 84 & 151 & $1.07(0.73,1.56)$ & * \\
\hline \multicolumn{5}{|l|}{ Type of salt } \\
\hline Packed & 16 & 14 & $2.39(1.15,4.99)$ & $2.23(1.01,4.89)$ \\
\hline Non-packed & 218 & 457 & 1.00 & 1.00 \\
\hline \multicolumn{5}{|l|}{ Salt exposure to sunlight } \\
\hline No & 225 & 445 & 1.00 & * \\
\hline Yes & 9 & 26 & $0.69(0.32,1.49)$ & * \\
\hline
\end{tabular}


Table 4 Factors associated with the availability of adequately iodized salt in the household, Dabat District, northwest, Ethiopia, March $2016(n=705)$ (Continued)

\begin{tabular}{|c|c|c|c|c|}
\hline \multicolumn{5}{|l|}{ Place of salt storage } \\
\hline Near to fire & 21 & 44 & $0.96(0.56,1.65)$ & * \\
\hline Away from fire & 213 & 427 & 1.00 & * \\
\hline \multicolumn{5}{|l|}{ Salt storage } \\
\hline With closed material & 222 & 447 & 1.00 & * \\
\hline Without closed material & 12 & 24 & $1.01(0.49,2.05)$ & * \\
\hline \multicolumn{5}{|l|}{ Duration of salt storage } \\
\hline $1-8$ weeks & 212 & 430 & 1.00 & * \\
\hline$\geq 9$ weeks & 22 & 41 & $1.09(0.63,1.87)$ & * \\
\hline \multicolumn{5}{|l|}{ Mother's knowledge } \\
\hline Poor & 113 & 272 & 1.00 & 1.00 \\
\hline Good & 121 & 199 & $1.46(1.07,2.00)$ & $1.49(1.08,2.08)$ \\
\hline \multicolumn{5}{|l|}{ Mother's attitude } \\
\hline Unfavorable & 81 & 183 & 1.00 & * \\
\hline Favorable & 153 & 288 & $1.20(0.86,1.66)$ & * \\
\hline \multicolumn{5}{|l|}{ Distance travel to buy salt } \\
\hline$\leq 60$ min walking & 180 & 329 & 1.00 & 1.00 \\
\hline$>60$ min walking & 54 & 142 & $0.69(0.48,0.99)$ & $0.68(0.48,0.99)$ \\
\hline
\end{tabular}

*didn't appear in the final model (not significant) using Backward LR

coarse texture of salt [1]. Given that loss of iodine is common in the case of the unpacked type of salt because of exposure to heat, moisture, and humidity $[33,38]$.

On the other hand, traveling longer distance to access shops enforces people to purchase a large amount of iodized salt at once which will increase the chance of losing iodine because of storing the salt for a longer period of time [13]. I line to this evidence, the current study indicated that the likelihood of having adequately iodized salt was lower in the respondents who traveled a longer distance to buy iodized salt compared to their counter parts.

Obviously, boosting mother's knowledge on iodized salt is an important step to ensure appropriate utilization of iodized salt in the household level [14, 28, 32]. Similarly, this study showed that the odds of having adequately iodized salt were higher among respondents who had good knowledge towards iodized salt compared to those who had poor knowledge. This could be related to the positive effect of mother's good knowledge in appropriately using and storing of iodized salt. A previous study also documented that poor iodine knowledge is the risk factors for IDDs [39].

Adequate training was given to field assistances (data collectors and supervisors) to improve the quality of data. Though mothers were clearly informed about the objective of the investigation, the study is not free from social desirability bias in responding the type of salt use and handling practice. Moreover, the semi-quantitative method was used to measure salt iodine content which may not reflect the actual availability of adequately iodized salt in the study area.

\section{Conclusions}

Despite Ethiopia has been implementing universal salt iodization since the last five years, the availability of iodized salt is well under the WHO recommendation in Dabat District. Therefore, strengthening measures to enhance community awareness on the benefit and handling practice of iodized salt is essential to improve availability of iodized salt. In addition to this, the focus needs to be on improving accessibility of iodized salt. Finally, the authors would like to recommend the future investigators to use iodometric titration method

\section{Abbreviations}

EPHI: Ethiopia Public Health Institute; HDSS: Health, and demographic surveillance system; ID: lodine deficiency; IDD: Iodine deficiency disorder; PCA: Principal component analysis; PPM: Parts per million; UNICEF: United Nations Children's Fund; WHO: World Health Organization

\section{Acknowledgements}

The authors would like to thank all respondents for their willingness to participate in the study. They are also grateful to North Gondar Zonal Health Department, Dabat District Health Office, Food and Nutrition Society of Ethiopia and the University of Gondar for their financial and material support. Finally, authors' appreciations go to Dabat HDSS site staffs for their unreserved contribution in data collection activities. 


\section{Funding}

This study was funded jointly by the Food and Nutrition Society of Ethiopia and the University of Gondar. The views presented in this manuscript are of the authors and not necessarily express the views of the funding organizations. The funding organizations were not involved in the design, data collection, analysis, and interpretation of the study.

\section{Availability of data and materials}

Data will be available upon request from the corresponding author.

\section{Authors' contributions}

ZA conceived the study, developed the tool, coordinated the data collection activity, carried out the statistical analysis and drafted the manuscript. AT participated in the design of the study, tool development, fund acquisition, data collection supervision, statistical analysis and drafting and reviewing the manuscript. EG participated in the design of the study and tool development, performed statistical analysis, and reviewing and editing the manuscript. All authors read and approved the final manuscript.

\section{Competing interests}

The authors declare that they have no competing interests.

\section{Consent for publication}

Not applicable.

\section{Ethics approval and consent to participate}

Ethical clearance was obtained from the Institutional Review Board of the Institute of Public Health, University of Gondar (Ref. No. IPH/2885/2016). The supportive letter was obtained from North Gondar Zonal Health Department and Dabat District Health Office. During house to house data collection, verbal informed consent was obtained from each respondent after briefly explaining the purpose, and benefit of the study. Health education about the use of iodized salt and handling practices were given to each respondent/mother after data collection. Confidentiality was maintained by avoiding personal identifiers and keeping the data locked.

\section{Publisher's Note}

Springer Nature remains neutral with regard to jurisdictional claims in published maps and institutional affiliations.

\section{Author details \\ ${ }^{1}$ Department of Human Nutrition, Institute of Public Health, College of Medicine and Health Sciences, University of Gondar, Gondar, Ethiopia. ${ }^{2}$ Department of Epidemiology and Biostatistics, Institute of Public Health, College of Medicine and Health Sciences, University of Gondar, Gondar, Ethiopia.}

Received: 5 December 2016 Accepted: 12 May 2017

Published online: 31 July 2017

\section{References}

1. World Health Organization, UNICEF, ICCIDD. Assessment of iodine deficiency disorders and monitoring their elimination. A guide for programme managers. Geneva: WHO; 2007.

2. Abuye $C$, Berhane $Y$. The goitre rate, its association with reproductive failure, and the knowledge of iodine deficiency disorders (IDD) among women in Ethiopia: Cross-section community based study. BMC Public Health. 2007;7(1):1.

3. Andersson M, De Benoist B, Darnton-Hill I, Delange F, editors. lodine deficiency in Europe: a continuing public health problem. Geneva: World Health Organization; 2007.

4. De Benoist B, Andersson M, Egli IM, El Bahi T, Allen H, World Health Organization. lodine status worldwide: WHO global database on iodine deficiency. 2004.

5. WHO, FAO. Guidelines on food fortification with micronutrients. Geneva: WHO and FAO; 2006.

6. Win AZ. Micronutrient deficiencies in early childhood can lower a country's GDP: The Myanmar example. Nutrition. 2016;32(1):138-40.

7. WHO. Guideline: fortification of food-grade salt with iodine for the prevention and control of iodine deficiency disorders. Geneva: World Health Organization; 2014
8. Pearce EN, Andersson M, Zimmermann MB. Global iodine nutrition: where do we stand in 2013?. Thyroid. 2013;23(5):523-8.

9. Jooste $\mathrm{P}$, Andersson M, Assey V. lodine nutrition in Africa: an update for 2014. Sight and Life. 2013;27(3):50-5.

10. Central Statistical Agency [Ethiopia] and ICF International. Ethiopia Demographic and Health Survey 2011. Addis Ababa, Calverton: Central Statistical Agency and ICF International; 2012.

11. Ethiopian public Health Institute. National salt iodization coverage towards Prevention of lodine Deficiency Disorder in Ethiopia. 2014.

12. Enyew HD, Zemedkun KG, Dagnaw AM. Prevalence of Goiter and Associated Factors Among Primary School Children Aged 6-12 Years Old in GobaTown, South East, Ethiopia. Int J Nutr Food Sci. 2015;4(3):381-7.

13. Matthys B, Davlatmamadova M, Karimova G, Jean-Richard V, Zimmermann $M B$, Wyss K. lodine nutritional status and risk factors for goitre among schoolchildren in South Tajikistan. BMC Endocr Disord. 2013;13(1):1.

14. Gidey B, Alemu K, Atnafu A, Kifle M, Tefera Y, Sharma H. Availability of Adequate lodized Salt at Household Level and Associated Factors in Rural Communities in Laelay Maychew District, Northern Ethiopia: A Cross Sectional Study. J Nutr Health Sci. 2015;2(1):1.

15. Kedir H, Berhane Y, Worku A. Subclinical lodine Deficiency among Pregnant Women in Haramaya District, Eastern Ethiopia. J Nutr Metab. 2014;2014:878926.

16. Zimmermann MB, Andersson M. Update on iodine status worldwide. Curr Opin Endocrinol Diabetes Obes. 2012;19(5):382-7.

17. Alsanosy RMA, Gaffar AM, Khalafalla HEE, Mahfouz MS, Zaid ANS, Bani IA. Current iodine nutrition status and progress toward elimination of iodine deficiency disorders in Jazan, Saudi Arabia. BMC Public Health. 2012;12(1):1.

18. Girma M, Loha E, Bogale A, Teyikie N, Abuye C, Stoecker BJ. lodine deficiency in primary school children and knowledge of iodine deficiency and iodized salt among caretakers in Hawassa Town: Southern Ethiopia. Ethiop J Health Dev. 2012;26(1):30-5.

19. Jaruratanasirikul S, Sangsupawanich $P$, Koranantakul O, Chanvitan P, Ruaengrairatanaroj P, Sriplung H. Maternal iodine status and neonatal thyroid-stimulating hormone concentrationa:community survey in Songkhla, southern Thailand. Public Health Nutr. 2009;12(12):2279-84.

20. Mezgebu Y, Mossie A, Rajesh P, Beyene G. Prevalence and serverity of lodine deficiency disorder among children 6-12 years of age in Shebe Senbo District, Jimma Zone, Southwest Ethiopia. Ethiop J Health Sci. 2012;22(3).

21. Adish A, Chuko T, Abay A, Assey V, Desta T. Ethiopia breaking through with new iodized salt. MI/UNICEF-Ethiopia/GAIN/ICCIDD iodine network/ FoH,Ethiopia. 2013.

22. Abuye C, Berhane Y, Akalu G, Getahun Z, Ersumo T. Prevalence of goiter in children 6 to 12 years of age in Ethiopia. Food Nutr Bull. 2007;28(4):391-8.

23. Mesele M, Degu G, Gebrehiwot H. Prevalence and associated factors of goiter among rural children aged $6-12$ years old in Northwest Ethiopia, cross-sectional study. BMC Public Health. 2014;14(1):1.

24. Aweke KA, Adamu BT, Girmay AM, Yohannes T, Alemnesh Z, Abuye C. lodine Deficiency Disorders (IDD) in Burie and Womberma Districts, West Gojjam, Ethiopia. Afr J Food Agric Nutr Dev. 2014;14(4):9167-80.

25. Abebe Z, Gebeye E, Tariku A. Poor dietary diversity, wealth status and use of un-iodized salt are associated with goiter among school children: a cross-sectional study in Ethiopia. BMC Public Health. 2017;17(44).

26. Li M, Eastman CJ. The changing epidemiology of iodine deficiency. Nat Rev Endocrinol. 2012:8(7):434-40.

27. Abbag Fl, Abu-Eshy SA, Mahfouz AA, Al-Fifi SA, El-Wadie H, Abdallah SM, et al. lodine-deficiency disorders in the Aseer region, south-western Saudi Arabia: 20 years after the national survey and universal salt iodization. Public Health Nutr. 2015;18(14):2523-9.

28. Aburto N, Abudou M, Candeias V, Wu T. Effect and safety of salt iodization to prevent iodine deficiency disorders: a systematic review with metaanalyses.WHO eLibrary of Evidence for Nutrition Actions (eLENA). Geneva: World Health Organization; 2014.

29. Andersson M, Karumbunathan V, Zimmermann MB. Global iodine status in 2011 and trends over the past decade. J Nutr. 2012;142(4):744-50

30. Zahidi A, Zahidi M, Taoufik J. Assessment of iodine concentration in dietary salt at household level in Morocco. BMC Public Health. 2016;16:418.

31. Gebriel TW, Assegid S, Assefa H. Cross-sectional Survey of Goiter Prevalence and Household Salt lodization Levels in Assosa Town, Beni Shangul-Gumuz Region, West Ethiopia. J Preg Child Health. 2014;1(119):2.

32. Gebremariam HG, Yesuf ME, Koye DN. Availability of Adequately lodized Salt at Household Level and Associated Factors in Gondar Town. Northwest Ethiopia: Hindawi Publishing Corporation; 2013. 
33. Kazungu K, Mbakaya C, Makokha A. Factors contributing to iodide deficiency in coast Province of Kenya. Eur J Res Med Sci. 2015;3(2):45-51.

34. Çan G, Ökten A, Green J. The role of local mass media in promoting the consumption of iodized table salt. Health Educ Res. 2001;16(5):603-7.

35. Makwana NR, Shah VR, Unadkat S, Shah HD, Yadav S. Goiter prevalence and current iodine deficiency status among school age children years after the universal salt iodization in Jamnagar district, India. Thyroid Res Pract. 2012; 9(2):40-4.

36. Hawas SB, Lemma S, Mengesha ST, Demissie HF, Segni MT. Proper Utilization of Adequatly lodized Salt at House Hold Level and Associated Factores in Asella Town Arsi Zone Ethiopia: A Community based Cross Sectional Study. J Food Process Technol. 2016;7(4):573.

37. Meselech Regassa D, Tsedeke Wolde H, Befirdu Mulatu J. Utilization of Adequately lodized Salt on Prevention of Iodine Deficiency Disorders at Household Level and Associated Factors in Lalo Assabi District, West Ethiopia. Nutr Food Sci. 2016;6(2):471.

38. Tololu AK, Getahun FA, Abitew DB. Coverage of lodized Salt and Associated Factors at Household Level in Goba Town, Bale Zone, South East Ethiopia. Sci J Public Health. 2016;4(4):346-51.

39. Kebede DL, Adinew YM. Predictors of Goiter among School Children in Southwest Ethiopia: CaseControl Study. Nutr Food Sci. 2015;5(3):1.

\section{Submit your next manuscript to BioMed Central} and we will help you at every step:

- We accept pre-submission inquiries

- Our selector tool helps you to find the most relevant journal

- We provide round the clock customer support

- Convenient online submission

- Thorough peer review

- Inclusion in PubMed and all major indexing services

- Maximum visibility for your research

Submit your manuscript at www.biomedcentral.com/submit 